\title{
Burden, quality of life and coping strategies of palliative care patients' caregivers
}

\section{Palyatif bakım hastalarının bakım verenlerinde bakım verenin yükü, başa} çıkma tutumları ve yaşam kalitesinin incelenmesi

\author{
Özge Timur ${ }^{1}$ \\ Nermin Gündüz ${ }^{2}$ Halime Altaş ${ }^{3}$ (D) \\ Hatice $\operatorname{Turan}^{4}(\mathbb{D}$ \\ Ömer Karaşahin ${ }^{5}$ D \\ Pınar Tosun Tasar $^{6}$ (D) \\ Doğan Nasır Binici ${ }^{1}$ \\ ${ }^{1}$ Erzurum Regional Training and Research Hospital, Internal Medicine Clinic, Erzurum, Turkey \\ ${ }^{2}$ NP Istanbul Brain Hospital Psychiatry Clinic, İstanbul, Turkey \\ ${ }^{3}$ Maltepe District Health Directorate, İstanbul, Turkey \\ ${ }^{4}$ Freelance Physician, Konya, Turkey \\ ${ }^{5}$ Erzurum Regional Training and Research Hospital, Infectious Diseases Clinic, Erzurum, Turkey \\ ${ }^{6}$ Ataturk University Hospital, Department of Internal Medicine, Division of Geriatrics, Erzurum, Turkey
}

\begin{abstract}
Aim: The burden of the caregiver can affect the caregiver socially, psychologically and physically in time. Since becoming a caregiver is always an unpredictable situation adaptation to this situation takes place after the situation arises. The aim of this study is to examine the attitudes of coping with caregiver burden and quality of life in caregivers of patients hospitalized in palliative care units.

Materials and Methods: The study was carried out with caregivers of 59 hospitalized patients in the palliative care unit of a university hospital. The Zarit caregiver burden scale was used to determine the caregiver burden, the SF 36 to determine the quality of life, and the COPE self-report scales to reveal the coping attitudes.

Results: The mean score of Zarit caregiver burden scale in caregivers was 50.7 and was interpreted as a moderate burden. The highest score among the COPE subscale scores was COPE 7 (religious coping) (15.7); the lowest score is COPE 12 (4.4) (Substance use). A significant negative correlation is found between the Zarit caregiver burden scale and the education level of the caregiver $(R=-0.291$, $\mathrm{p}=0.025)$.

Conclusion: Caregiver burden is the totality of possible physical, psychological, social or financial responses while providing care. In our country, mostly women, unemployed and low-educated family members become caregiving. In our study, the participants defined a moderate burden, although they provided care to chronic and severe patients. This indicates that in addition to the treatment of patients in palliative care centers, caregivers are also provided with medical, social and psychological support.
\end{abstract}

Keywords: Palliative care, caregiver, caregiver burden.

\section{ÖZ}

Amaç: Bakım veren kişi üzerinde oluşan maddi ve manevi yük; zamanla bakım vereni sosyal, psikolojik ve fiziksel olarak olumsuz etkileyebilmektedir. Bakım veren haline gelme her zaman öngörülemez bir durum olduğundan bu duruma uyum, durum ortaya çıktıktan sonra gerçekleşmektedir. Bu çalışmanın amacı, palyatif bakım ünitesinde yatmakta olan hastaların bakım verenlerinde bakım verenin yükü ile başa çıkma tutumları ve yaşam kalitesinin irdelenmesidir.

Corresponding author: Pınar Tosun Tasar

Erzurum Regional Training and Research Hospital, Internal

Medicine Clinic, Erzurum, Turkey

E-mail: pinar.tosun@gmail.com 
Gereç ve Yöntem: Çalışma bir üniversite hastanesi palyatif bakım biriminde yatmakta olan 59 hastanın bakım verenleri ile gerçekleştirilmiştir. Bakım veren yükünü belirlemek için Zarit Bakım Verenin Yükü, yaşam kalitesini belirlemek için SF 36 ve başa çıkma tutumlarını ortaya koymak için COPE öz bildirim ölçekleri kullanılmış olup ölçekler sosyal hizmet uzmanı eşliğinde doldurulmuştur.

Bulgular: Bakım verenlerde Zarit Bakım veren Yükü ölçeğinin ortalama puanı 50,7 olup orta düzeyde yük olarak yorumlanmıştır. COPE alt ölçek puanlarından en yüksek puan COPE 7 (Dinî olarak başa çıkma) (15,7); en düşük puan COPE 12 (4,4) (Madde kullanımı)'dır. Zarit bakım veren yükü ölçeği ile bakım verenin eğitim durumu arasında negatif yönlü anlamlı korelasyon saptanmıştır $(R=-0,291$, $p=0,025)$.

Sonuç: Bakım veren yükü, bakım sunarken ortaya çıkması olası fiziksel, psikolojik, sosyal veya finansal tepkiler bütünüdür. Ülkemizde bakım verme işini genellikle kadın, çalışmayan, eğitim seviyesi düşük aile bireyleri üstlenmektedir. Çalışmamızda kronik ve ağır hastalara bakım vermelerine rağmen katıımcılar orta derecede yük tanımlamışlardır. Bu durum palyatif bakım merkezlerinde hastaların tedavisinin yanı sıra bakım verenlerine de tıbbi, sosyal ve psikolojik olarak destek sunulduğunu göstermektedir.

Anahtar Sözcükler: Palyatif bakım, bakım veren, bakım veren yükü.

\section{INTRODUCTION}

Palliative care is a multidisciplinary approach to increase the quality of life of people with severe disease and to prevent complications due to the disease (1). Palliative care, as defined by the World Health Organization (WHO), not only aims to maintain quality of life of patients, but also support caregivers (2). WHO predicts that palliative care units should be established to serve in all countries regardless of their level of development. In our country, the number of people receiving palliative care and palliative care units has been increasing in recent years.

Caregiving is a situation that has different dimensions for the care recipient and the caregiver. The economic and moral burden on the caregiver may negatively affect the caregiver socially, psychologically and physically over time. Burden is defined as negative subjective and objective consequences such as psychological distress, physical health problems, economic and social problems, deterioration of family relations and loosing the control. The caregiver feels obliged to provide the patient's treatment, personal care and psychosocial support $(3,4)$. In addition, the fear of being aware that the patient they give caregiving is approaching the end of his / her life is one of the emotions that the caregiver should deal with (5). Since becoming a caregiver is an unpredictable situation, adaptation to this situation occurs after the situation arises (6).

Determining the demographic characteristics of caregivers, especially those who give care patients with chronic diseases, may help to identify the group at risk in terms of experiencing difficulties. Thus, the coping strategies and quality of life of this group can be determined and preventive mental health services can be planned for these people. The aim of this study is to examine the strategies of coping with caregiver burden and quality of life in caregivers of hospitalized patients in palliative care units.

\section{MATERIALS AND METHODS}

Our study was conducted with the caregivers of 59 hospitalized patients in the palliative care unit of the Health Sciences University in our region between February 1, 2016 and April 30, 2016. The data were collected using face-to-face interview technique, and the data regarding the disease were obtained from the patients and the patients' file. The study was carried out by obtaining the necessary permissions from the ethics committee of the Health Sciences University Hospital in our region (ethics committee number 02-11 dated 19.01.2016). The caregivers of the patients who volunteered to participate in the study were informed and their signed consent form was obtained.

Demographic characteristics of the patients included in the study (such as age, gender, place of residence, working status, marital status, number of children), nutritional status at the time of assessment, toilet use, self-care availability, bed dependency, days of palliative care stay, geriatric syndromes (such as urinary incontinence, gaita incontinence, falls, decubitus, dementia, delirium, malnutrition, frailty) and their number has been recorded. In addition, the 
demographic data of the caregiver (such as age, gender, marital status, employment status, educational status, chronic illnesses, smoking habits), psychiatric illness of the caregiver, the degree of closeness between the caregiver and the patient, the number of dependents of the caregiver and the duration of care for the patient has been recorded.

Zarit Caregiver Burden scale was used to determine caregiver burden, SF 36 to determine quality of life, and COPE self-report scale to reveal coping strategies. Scales were filled in the presence of a social services specialist.

The Zarit caregiver burden scale was developed by Zarit et al. (7) in 1980; developed to evaluate the stress experienced by the caregiver, translated to Turkish by Inci et al. (8). This highly reliable scale consists of 22 questions and is evaluated as Likert type. It is a 5-level scale scored as "0, never", "4, almost always". The minimum score which can be obtained from the scale is 0 and the maximum score is 88 . Between 0-21 is evaluated as "no burden-low level", 21-40 as "mild-moderate", 41-60 as "moderate-severe", 61-88 as "severe" burden perception. The higher score represents higher burden.

The COPE scale, which evaluates coping strategies, was developed by Carver et al. (9) in 1989 and translated to Turkish by Ağargün et al (10). It consists of 60 questions with a score of 1 4 and 15 subscales $(9,10)$.

Each subscale consists of four questions. Each of these subscales provides information about a separate coping strategy. As a result, the higher scores to be obtained from the subscales give the possibility to comment on which coping strategy which is used more often. The subscales are:

1. Positive reinterpretation and improvement: 1, 29, 38, 59

2. Mental disengagement: $2,16,31,43$

3. Focus on and venting of emotions: 3,17 , 28,46

4. Use of instrumental social support: 4,14 , 30,45

5. Active coping: $5,25,47,58$

6. Denial: $6,27,40,57$

7. Religious coping: $7,18,48,60$

8. Humor: $8,20,36,50$

9. Behavioral disengagement: $9,24,37,51$

10. Restraint-coping: $10,22,41,49$

11. Use of emotional social support: 11,23 , 34,52
12. Substance use: $12,26,35,53$

13. Acceptance: $13,21,44,54$

14. Suppression of competing activities: 15 , $33,42,55$

15. Planing: $19,32,39,56$

A 60 -item form with 15 factors, each consisting of four items was created. These factors are theoretically included in three dimensions. These; problem-focused coping (4., 5., 14., 15. factor), emotion focused coping (1.7.8, 11.13 factor), dysfunctional coping (2., 3., 6., 9., 10., 12. factor). SF-36 (Short Form 36) scale was used to determine the quality of life. Turkish validity and reliability of SF-36 was made by Koçyiğit et al. (11). SF-36 consists of two main dimensions, physical and mental, and eight subscales. Information about physical and social function, physical and emotional role restrictions, mental health, vitality, pain and general perception of health can be obtained. It can reveal the positive and negative aspects of health status. Physical function and mental health subscale scores of SF-36 were used in our study.

The SPSS-21 package program was used to record and analyze the data. Descriptive statistics were used in the evaluation of the data and the data were presented with median (minimum - maximum), number and percentage distribution. Chi-square and Mann-Whitney $U$ tests were used to compare the data. The correlation of the Zarit Caregiver Burden Scale with other data was performed using the Spearman test. $p<0.05$ was considered significant.

\section{RESULTS}

The mean age of 59 patients, 32 (54.2\%) female and $27(45.8 \%)$ male, who were hospitalized in the palliative care unit, was $74.20 \pm 14.22$. 25 $(42.4 \%)$ of the caregivers of these patients are male, $34(57.6 \%)$ were female and the mean age was $44.10 \pm 12.42$. The characteristics of patients and caregivers were presented in Table-1.

Some descriptive characteristics of the patients and the scores they got from the Zarit caregiver burden scale, the subscales of the COPE scale, the SF-36 quality of life scale, and Problemfocused coping, Emotion-focused coping, and dysfunctional coping were evaluated. Statistically significant results were presented in Table-2. The mean \pm standard deviation scores of the applied scales were presented in Table-3. 
Table-1. Descriptive characteristics of patients and caregivers.

\begin{tabular}{|c|c|c|}
\hline Characteristics & Patientn, (\%) & Caregivern, (\%) \\
\hline \multicolumn{3}{|l|}{ Gender } \\
\hline Male & $32(54.2)$ & $25(42.4)$ \\
\hline Female & $27(45.8)$ & $34(57.6)$ \\
\hline Age (year) & $76(20-102)^{*}$ & $44(19-73)$ \\
\hline \multicolumn{3}{|l|}{ Marital Status } \\
\hline Single & $14(23.7)$ & $32(54.2)$ \\
\hline Married & $13(22.0)$ & $22(37.3)$ \\
\hline Other & $32(32)$ & $5(8.5)$ \\
\hline \multicolumn{3}{|l|}{ Education Status } \\
\hline illiterate & $32(54.2)$ & $5(8.5)$ \\
\hline Literate & $4(6.8)$ & $3(5.1)$ \\
\hline Primary school & $18(30.5)$ & $34(57.6)$ \\
\hline Secondary school & $1(1.7)$ & $5(8.5)$ \\
\hline High school & $4(6.8)$ & $5(8.5)$ \\
\hline University & - & $7(11.9)$ \\
\hline \multicolumn{3}{|l|}{ Working Status } \\
\hline Unemployed & $59(100)$ & $22(37.3)$ \\
\hline Employed & - & $37(62.7)$ \\
\hline \multicolumn{3}{|l|}{ Living Place } \\
\hline Own house & $33(55.9)$ & - \\
\hline Childrens' house & $25(42.4)$ & - \\
\hline Nursing Home & $1(1.7)$ & - \\
\hline \multicolumn{3}{|l|}{ Nutritional Status } \\
\hline Oral & $40(67.8)$ & - \\
\hline Nasal & $7(11.9)$ & - \\
\hline TPN & $12(20.3)$ & - \\
\hline No Toilet Use & $50(84.7)$ & - \\
\hline No Self-care & $52(88.1)$ & - \\
\hline Bed Dependent & $46(78.0)$ & - \\
\hline Smoking & - & $17(28.8)$ \\
\hline IIIness & & $5(8.5)$ \\
\hline Urinary Incontinence & $59(100)$ & - \\
\hline Gaita Incontinence & $34(57.6)$ & - \\
\hline Fall & $33(55.9)$ & - \\
\hline Decubitis & $26(44.1)$ & - \\
\hline Demantia & $30(50.8)$ & - \\
\hline Delirium & $32(54.2)$ & - \\
\hline Malnutrition & $28(47.5)$ & - \\
\hline Frailty & $41(69.5)$ & - \\
\hline Psychiatric illness & $55(74.6)$ & $2(3.4)$ \\
\hline \multicolumn{3}{|l|}{ Caregiver } \\
\hline Spouse & - & $5(8.5)$ \\
\hline Sibling & - & $3(5.1)$ \\
\hline Child & - & $37(62.7)$ \\
\hline Father & - & $2(3.4)$ \\
\hline Other Relative & - & $11(18.6)$ \\
\hline Other & - & $1(1.7)$ \\
\hline Number of Children & $6(0-12)^{*}$ & - \\
\hline Days in palliative care unit & $7(0-63)^{*}$ & - \\
\hline Number of geriatric syndromes & $4(0-5)^{*}$ & - \\
\hline Number of Dependents & & $4(0-10)^{*}$ \\
\hline Caregiving Duration (months) & & $120-120)^{*}$ \\
\hline
\end{tabular}

"Median Value (maximum-minimum); TPN, total parenteral nutrition 
Table-2. Significant results between descriptive characteristics and scales.

\begin{tabular}{|c|c|c|c|}
\hline Scales & Caregivers & $\begin{array}{l}\text { Scale score } \\
\text { Mean } \pm \text { SD }\end{array}$ & p \\
\hline \multicolumn{4}{|c|}{ SF-36 Physical Activity } \\
\hline & Caregivers of patients with self-care & $85.31 \pm 21.75$ & 0.021 \\
\hline & Caregivers of patients without self-care & $60.86 \pm 21.41$ & \\
\hline & Caregivers of falling patients & $74.52 \pm 23.97$ & 0.019 \\
\hline & Caregivers of patients who did not fall & $45.00 \pm 12.78$ & \\
\hline & Caregivers of patients with delirium & $68.19 \pm 21.27$ & 0.025 \\
\hline & Caregivers of patients without delirium & $59.77 \pm 21.99$ & \\
\hline & Caregivers of frail patients & $67.19 \pm 22$ & 0.025 \\
\hline & Caregivers of non-frail patients & $53.71 \pm 16.88$ & \\
\hline \multicolumn{4}{|c|}{ SF-36 Mental Health } \\
\hline & Caregivers of patients with fecal incontinence & $51.44 \pm 13.64$ & 0.041 \\
\hline & Caregivers of patients without fecal incontinence & $45.32 \pm 12.64$ & \\
\hline & Caregivers of patients with decubitus & $52.37 \pm 13.28$ & 0.019 \\
\hline & Caregivers of patients without decubitus & $45.0 \pm 12.78$ & \\
\hline & Caregivers of falling patients & $55.93 \pm 13.30$ & $<0.001$ \\
\hline & Caregivers of patients who do not fall & $43.08 \pm 10.71$ & \\
\hline \multicolumn{4}{|c|}{ COPE-15 (Planinig) } \\
\hline & Caregivers of bedridden patients & $12.91 \pm 1.99$ & 0.042 \\
\hline & Caregivers of non-bedridden patients & $11.92 \pm 1.75$ & \\
\hline \multicolumn{4}{|c|}{ COPE- 2 (Mental Disengagement) } \\
\hline & Caregivers of patients with dementia & $10.12 \pm 1.89$ & 0.039 \\
\hline & Caregivers of patients without dementia & $9.07 \pm 2.12$ & \\
\hline \multicolumn{4}{|c|}{ COPE- 3 (Focus on and venting of emotions) } \\
\hline & Caregivers of nasal feding patients & $13.28 \pm 2.36$ & \\
\hline & Caregivers of oral feding patients & $10.37 \pm 3.33$ & 0.046 \\
\hline & Caregivers of TPN feding patients & $11.91 \pm 2.87$ & \\
\hline \multicolumn{4}{|c|}{ COPE- 4 (Use of instrumental social support) } \\
\hline & Caregivers of nasal feding patients & $13.57 \pm 1.27$ & \\
\hline & Caregivers of oral feding patients & $11.55 \pm 2.22$ & 0.013 \\
\hline & Caregivers of TPN feding patients & $13.25 \pm 1.86$ & \\
\hline \multicolumn{4}{|c|}{ COPE 11 (Use of emotional social support) } \\
\hline & Caregivers of nasal feding patients & $12.85 \pm 3.28$ & \\
\hline & Caregivers of oral feding patients & $9.67 \pm 2.96$ & 0.015 \\
\hline & Caregivers of TPN feding patients & $11.58 \pm 3.11$ & \\
\hline
\end{tabular}

SD, standart deviation; TPN, total parenteral nutrition 
Table-3. Mean \pm standard deviation scores of the scales.

\begin{tabular}{lc}
\hline Scales & Mean \pm SD \\
\hline Zarit & $50.7 \pm 10.7$ \\
SF-36 Physical Activity & $63.7 \pm 21.8$ \\
SF-36 Mental Health & $48.7 \pm 13.4$ \\
COPE sub-scales & \\
$\quad$ Positive reinterpretation and improvement & $14.0 \pm 1.6$ \\
$\quad$ Mental disengagement & $9.6 \pm 2.0$ \\
Focus on and venting of emotions & $11.0 \pm 3.2$ \\
$\quad$ Use of instrumental social support & $12.1 \pm 2.2$ \\
$\quad$ Active coping & $12.1 \pm 2.0$ \\
Denial & $4.9 \pm 2.1$ \\
Religious coping & $15.7 \pm 1.5$ \\
Humor & $6.2 \pm 2.3$ \\
Behavioral disengagement & $5.7 \pm 2.1$ \\
Restraint & $11.1 \pm 2.1$ \\
$\quad$ Use of emotional social support & $10.4 \pm 3.1$ \\
Substance use & $4.4 \pm 2.0$ \\
Acceptance & $13.1 \pm 1.9$ \\
Suppression of competing activities & $10.7 \pm 1.7$ \\
Planing & $12.6 \pm 1.9$ \\
Problem-focused coping & $58.5 \pm 7.2$ \\
Dysfunctional coping & $60.1 \pm 5.7$ \\
\hline
\end{tabular}

SD, standard deviation

Table-4. Correlations between Zarit caregiver burden scale and scores obtained from each subscale of COPE and SF-36 quality of life scale.

\begin{tabular}{lcc}
\hline Scales & $\mathbf{r}$ & $\mathbf{p}$ \\
\hline Positive reinterpretation and improvement & -0.005 & 0.969 \\
Mental disengagement & 0.321 & $\mathbf{0 . 0 1 3}$ \\
Focus on and venting of emotions & 0.095 & 0.475 \\
Use of instrumental social support & 0.215 & 0.103 \\
Active coping & 0.163 & 0.217 \\
Denial & -0.118 & 0.372 \\
Religious coping & 0.052 & 0.694 \\
Humor & -0.049 & 0.711 \\
Behavioral disengagement & 0.096 & 0.471 \\
Restraint & 0.244 & 0.063 \\
Use of emotional social support & 0.171 & 0.194 \\
Substance use & 0.190 & 0.149 \\
Acceptance & 0.276 & $\mathbf{0 . 0 3 4}$ \\
Suppression of competing activities & 0.044 & 0.743 \\
Planing & -0.009 & 0.947 \\
SF-36 Physical Activity & 0.091 & 0.494 \\
SF-36 Mental Health & 0.033 & 0.803 \\
Problem-focused coping & 0.188 & 0.154 \\
Emotion focused coping & 0.174 & 0.189 \\
Dysfunctional coping & 0.203 & 0.123 \\
\hline
\end{tabular}


Correlations between Zarit caregiver burden scale, and the scores obtained from each subscale of COPE and SF-36 quality of life scale were made. A statistically significant relationship was found between the Zarit caregiver burden scale and the COPE-2 and COPE-13 (mental disengagement and acceptance) subscales $(r=0.321, p=0.013 ; r=0.276, p=0.034$, respectively). Related data were presented in Table-4.

The mean score of Zarit caregiver burden scale was 50.7, and it was interpreted as a moderate burden. The mean scale score was 51.9 for females, and 49.2 for males. This difference was not statistically significant $(p=0.429)$. The highest score from the COPE subscale was COPE-7 (religious coping) (15.7); the lowest score is COPE-12 (4.4) (substance use). Emotional focused coping score was the highest, dysfunctional coping score was the lowest.

A weak positive correlation was found between the Zarit caregiver burden scale and the COPE-2 scale (mental disengagement) $(r=0.280 ; p=$ 0.032 ). Statistically significant difference was not found between the Zarit caregiver burden scale and the descriptive characteristics of the patients.

A negative significant correlation was found between the Zarit caregiver burden scale and the education level of the caregiver $(r=-0.291$, $p=0.025)$.

\section{DISCUSSION}

Since becoming a caregiver is not a chosen or planned process, it creates a physical and psychological burden on the caregiver. The caregiver who is negatively affected in emotional and social aspects also causes the person in need of care to be negatively affected (12). Caregiver burden is the whole of possible physical, psychological, social or financial reactions while caregiving (7). In the sociocultural structure of our country, it is a common behavior for family members to take care of their relatives in need. The person can perceive caregiving as his / her own duty and responsibility, as a result, the caregiver can define the burden less. In cases where the burden of caregiving is not noticed in its real dimension, the search for psychological, physical and social support that the caregiver can take from outside to eliminate or alleviate the burden may decrease, and more individual solutions such as mental disengagement and spiritual feelings may be directed.
In our country, caregiving is generally undertaken by women, and family members who are unemployed and have a low education level (13). However, this situation is not specific to Turkish population. In the study conducted by Lin et al., $63.3 \%$ of the caregivers were women (14). In our study, $57.6 \%$ of caregivers were women. This finding is consistent with the literature.

The studies have shown that female gender increases caregiver burden and decreases caregiver's quality of life $(15,16)$. It is a wellknown fact that in addition to the compassionate, healing role and natural self-sacrifice of women, they also have a caregiving role within the scope of their traditional roles. It has been reported that women see caregiving as a continuation of their former responsibilities, and men are unfamiliar with their caregiving responsibilities (12). In a study conducted by $\mathrm{Kim}$ et al. (17) with 448 caregivers of cancer patients, it was shown that male caregivers perceive caregiving as a situation that supports their self-confidence, and that men experience caregiving work less stressful than women. In addition, it has been reported that the care burden perceived by women is higher than men $(18,19)$.

In studies in the literature, Zarit caregiving burden scale score was found to be higher in women than in men $(15,20)$. In our study, although the caregiving burden scale score was found to be higher in women compared to men, it did not reach a statistically significant value.

In our study, $62.7 \%$ of the caregivers were determined as the child of the patient and $8.5 \%$ as their spouse. In a study, Pang et al. (21) showed that caregivers are mostly spouses. However, studies conducted in our country have shown that caregivers are mostly the children of the patients (22-24). This may be due to the characteristics of the Turkish family structure. In our society, children are expected to provide care to their parents and live with them when needed (24). In our study, it was found that $42.4 \%$ of the patients who lived in their children's home.

In our study, the mean score of the Zarit caregiver burden questionnaire was determined as 50.7 and interpreted as moderate burden. When the patients in need of care were examined, it was found that $84.7 \%$ of the patients could not meet their toilet needs alone, $78 \%$ were bed-dependent, $88.1 \%$ could not provide selfcare, $50.8 \%$ had decubitus and $54.2 \%$ had 
dementia. It is expected that the burden of caregivers will be high in those who care for patients who have such a high need for care and cannot meet their daily needs on their own. Studies have also reported that caregiving burden of caregivers of dependent patients is higher than caregivers of semi-dependent or independent patients $(25,26)$.

However, a moderate burden was found in our study. This situation made us think that due to the nature of our society, caregivers avoid from expressing the burden, that the burden is perceived as avoiding responsibility, and therefore they feel guilt, despair, anger and fear towards them. However, we think that the palliative care services are effective in the moderate perception of burden. The burden perception of the caregiver who does not feel alone and helpless during the caregiving process decreases.

When the educational status of the caregivers was examined, it was determined that $8.5 \%$ were illiterate, $5.1 \%$ were literate and $57.6 \%$ were primary school graduates. There was a significant negative correlation between Zarit caregiver burden and education level of the caregiver. It was observed that as the educational status of the caregiver decreased, the Zarit caregiver scale score increased, in other words, the concept of burden perceived by the person increased. Studies have also found that caregivers with a low level of education have a higher burden $(25,27)$.

When coping strategies were examined in our study, it was found that religious coping was the most preferred and the least preferred was substance use. However, only alcohol and drugs were questioned as substance use, smoking was not questioned. Paying attention to religious values in the region where our study was conducted may cause the religious coping to be preferred more. A person who has been brought up with the teachings of praying throughout her / his life, taking shelter in God, and thinking that she/he is with God when feeling helpless, tries to overcome caregiver burden with religious coping as she / he knows best. In addition, this situation is not only eligible for our region. Studies have also shown that caregivers reduce their caregiving burden with belief and fate perception (28). The fact that substance use is not preferred as a coping strategy may be related to the perception of this behavior as a sin in our society.

The quality of life of the patient in need of care is closely related to the quality of life of the caregiver $(29,30)$. In palliative care units, psychosocial needs of caregivers are met in addition to the care of patients. This situation is very important and beneficial in adapting to the caregiver role (31).

In our study, situations requiring different care were examined in the same study. This is the limitation of our study. However, our study contributes to the literature in order to turn care responsibility into the concept of burden and to examine coping strategies.

\section{CONCLUSION}

As a result, it is very important for the caregiver to know the difficulties they will face, to develop strategies to cope with them, and to access social support when needed. Palliative care units, where caregivers can access social and professional support, increase quality of life of caregivers and consequently the quality of life of the patients by reducing the care burden.

Conflict of Interest: The authors declared no conflict of interest.

\section{References}

1. Morrison RS, Meier DE. Clinical practice. Palliative care. N Engl J Med 2004; 350: 2582-90.

2. World Health Organization, https://www.who.int/can-cer/palliative/definition/en/ (Accessed on 20.05.2020).

3. Weibull A, Olesen F, Neergaard MA. Caregivers' active role in palliative home care - to encourage or to dissuade? A qualitative descriptive study. BMC Palliat Care 2008; 7: 15.

4. Lund L, Ross L, Petersen MA, Groenvold M. Cancer caregiving tasks and consequences and their associations with caregiver status and the caregiver's relationship to the patient: a survey. BMC Cancer 2014; $14: 541$.

5. De Korte-Verhoef MC, Pasman HR, Schweitzer BP, et al. Burden for family carers at the end of life; a mixedmethod study of the perspectives of family carers and GPs. BMC Palliat Care 2014; $13: 16$.

6. Eicher PS, Batshaw ML. Cerebral palsy. Pediatr Clin North Am 1993; 40: 537-51. 
7. Zarit SH, Reever KE, Bach-Peterson J. Relatives of the impaired elderly: correlates of feelings of burden. Gerontologist 1980; 20: 649-55.

8. İnci $F$, Erdem M. Bakım verme yükü ölçeği'nin Türkçe'ye uyarlanması geçerlilik ve güvenilirliliği. Atatürk Üniversitesi Hemşirelik Yüksekokulu Dergisi 2008; 11: 85-95.

9. Carver CS, Scheier MF, Weintraub JK. Assessing coping strategies: a theoretically based approach. J Pers Soc Psychol 1989; 56: 267-83.

10. Ağargün M, Beşiroğlu L, Kıran Ü, et al. COPE (Başa Çıkma Tutumlarını Değerlendirme Ölçeği): Psikometrik özelliklere ilişkin bir ön çalışma. Anadolu Psikiyatri Dergisi 2005; 6: 221-6.

11. Koçyiğit $H$, Aydemir Ö, Ölmez N, Memiş A. Kısa form-36 (KF36)'nın Türkçe versiyonunun güvenirliliği ve geçerliliği. İlaç ve Tedavi Dergisi 1999; 12: 102-6.

12. Atagün M, Balaban Ö, Atagün Z, et al. Kronik Hastalıklarda Bakım Veren Yükü Caregiver Burden in Chronic Diseases. Psikiyatride Güncel Yaklaşımlar-Current Approaches in Psychiatry 2011; 3: 513-52.

13. Zaybak $A$, Güneş Ü, İsmailoğlu $E$, Ülker $E$. Yatağa bağımlı hastalara bakım veren bireylerin bakım yüklerinin belirlenmesi. Anadolu Hemşirelik ve Sağık Bilimleri Dergisi 2012; 15.

14. Lin PC, Lu CM. Hip fracture: family caregivers' burden and related factors for older people in Taiwan. J Clin Nurs 2005; 14: 719-26.

15. Adelman RD, Tmanova LL, Delgado D, et al. Caregiver burden: a clinical review. JAMA 2014; 311: 1052-60.

16. Kim H, Chang M, Rose K, Kim S. Predictors of caregiver burden in caregivers of individuals with dementia. J Adv Nurs 2012; 68: 846-55.

17. Kim Y, Baker F, Spillers RL. Cancer caregivers' quality of life: effects of gender, relationship, and appraisal. J Pain Symptom Manage 2007; 34: 294-304.

18. Mcllfatrick S, Doherty LC, Murphy M, et al. 'The importance of planning for the future': Burden and unmet needs of caregivers' in advanced heart failure: A mixed methods study. Palliat Med 2018; 32: 881-90.

19. Friethriksdottir N, Saevarsdottir T, Halfdanardottir SI, et al. Family members of cancer patients: Needs, quality of life and symptoms of anxiety and depression. Acta Oncol 2011; 50: 252-8.

20. Rha SY, Park Y, Song SK, et al. Caregiving burden and the quality of life of family caregivers of cancer patients: the relationship and correlates. Eur J Oncol Nurs 2015; 19: 376-82.

21. Pang FC, Chow TW, Cummings JL, et al. Effect of neuropsychiatric symptoms of Alzheimer's disease on Chinese and American caregivers. Int J Geriatr Psychiatry 2002; 17: 29-34.

22. Tuna $\mathrm{M}$, Olgun $\mathrm{N}$. İnmeli hastalara bakım veren hasta yakınlarında görülen tükenmişlik durumunda algılanan sosyal desteğin rolü. Hacettepe Üniversitesi Sağlık Bilimleri Fakültesi Hemşirelik Dergisi 2010; 17: 41-52.

23. Akgün Z. Kronik obstrüktif akciğer hastalarına (Koah) bakım veren bireylerin bakım yükü ve depresyon düzeyleri. Tıp Araştırmaları Dergisi 2014; 12: 113-9.

24. Taşkın Egici M, Kök Can M, Toprak D, et al. Care Burden and Burnout Status of Caregivers Whose Patients are Treated in Palliative Care Centers. JAREN 2019; 5: 123-31.

25. Weitzner MA, McMillan SC, Jacobsen PB. Family caregiver quality of life: differences between curative and palliative cancer treatment settings. J Pain Symptom Manage 1999; 17: 418-28.

26. Yıldııım S, Engin E, Başkaya V. Inmeli Hastalara Bakım Verenlerin Yükü ve Yükü Etkileyen Faktörler. Nöropsikiyatri Arşivi 2013; 50: 169-74.

27. Dirikkan F, Baysan Arabaci L, Mutlu E. The caregiver burden and the psychosocial adjustment of caregivers of cardiac failure patients. Turk Kardiyol Dern Ars 2018; 46: 692-701.

28. Spatuzzi R, Giulietti MV, Ricciuti M, et al. Exploring the associations between spiritual well-being, burden, and quality of life in family caregivers of cancer patients. Palliat Support Care 2019; 17: 294-9.

29. Philip RR, Philip S, Tripathy JP, et al. Twenty years of home-based palliative care in Malappuram, Kerala, India: a descriptive study of patients and their care-givers. BMC Palliat Care 2018; 17: 26.

30. Krug K, Miksch A, Peters-Klimm F, et al. Correlation between patient quality of life in palliative care and burden of their family caregivers: a prospective observational cohort study. BMC Palliat Care 2016; 15: 4.

31. Mohamed S, Rosenheck R, Lyketsos CG, Schneider LS. Caregiver burden in Alzheimer disease: crosssectional and longitudinal patient correlates. Am J Geriatr Psychiatry 2010; 18: 917-27. 